\title{
Upaya Meningkatkan Motivasi Dan Hasil Belajar Seni Budaya Pokok Bahasan Pembuatan Batik Tulis Dengan Model Pembelajaran Project Based Learning Pada Siswa Kelas VIIA SMP Negeri 4 Jonggat Tahun Pelajaran 2018/2019
}

\author{
Eny Purwindari \\ Guru Seni Budaya SMP Negeri 4 Jonggat, Lombok Tengah
}

\begin{abstract}
Abstrak. Penelitian ini bertujuan untuk mengetahui peningkatan motivasi dan hasil belajar Seni Budaya siswa kelas VIIA SMP Negeri 4 Jonggat Kabupaten Lombok Tengah pada pokok bahasan Batik Tulis menggunakan model pembelajaran Project Based Learning. Penelitian ini merupakan penelitian tindakan kelas yang dilakukan oleh guru sekaligus sebagai peneliti dalam setiap pertemuann dibantu oleh satu orang pengamat. Obyek penelitian tindakan ini adalah siswa kelas VIIA SMP Negeri 4 Jonggat semester genap tahun pelajaran 2018/2019 yang berjumlah 25 orang. Penelitian ini dilakukan dalam dua siklus, tiap siklusnya terdiri atas tiga pertemuan. Pengumpulan data dilakukan melalui observasi, dokumentasi, dan tes hasil belajar. Hasil penelitian menunjukkan adanya peningkatan hasil belajar Seni Budaya siswa kelas VIIA SMP Negeri 4 Jonggat semester genap tahun pelajaran 2018/2019 setelah diadakan tindakan berupa pembelajaran dengan model Project Based Learning. Kegiatan pembelajaran meliputi : persiapan guru dan siswa dalam memulai pembelajaran, pengelompokan, pembahasan pokok bahasan, pelaksanaan pembelajaran melalui teori dan praktik, penyimpulan pokok bahasan dan penugasan serta persiapan pada pokok bahasan berikutnya. Hasil observasi menunjukkan banyaknya siswa yang termotivasi pada saat pembelajaran adalah $88 \%$. Hasil belajar Seni Budaya membatik tulis menunjukkan ratarata penguasaan praktik sebesar 84,3 dan banyaknya siswa yang tuntas mencapai $92 \%$. Berdasarkan analisis data, diperoleh bahwa indikator keberhasilan telah tercapai, sehingga peneliti menyimpulkan bahwa (1) model pembelajaran project based learning dapat meningkatkan hasil belajar Seni Budaya siswa kelas VIIA SMP Negeri 4 Jonggat pada pokok bahasan batik tulis semester genap tahun pelajaran 2018/2019; dan (2) model pembelajaran project based learning dapat meningkatkan hasil belajar Seni Budaya siswa kelas VIIA SMP Negeri 4 Jonggat pada pokok bahasan Batik Tulis semester genap tahun pelajaran 2018/2019.
\end{abstract}

\section{Kata kunci : Motivasi Belajar, Hasil belajar, Project Based learning}

Abstract. of learning project based learning on even-numbered years semester lesson 2018/2019. This is a classroom action research conducted by teachers as well as researchers in every meeting is assisted by one person observer. Subjek this action research were teacher and students of class VIIA SMP Negeri 4 Jonggat second semester of academic year 2018/2019. The study was conducted in two cycles, each cycle consisting of three meetings. Technique data collecting is done through observation, documentation and learning outcomes. The results showed an increase in students' learning outcomes Cultural Arts class VIIA SMP Negeri 4 Jonggat after the holding action in the form of learning with models Project Based Learning activities include teacher preparation and start learning, grouping, discussion of materials, execution learning through theory and practice, the inference materials and assignments as well as the preparation of the material. observation indicates the number of students who are motivated when learning is $88 \%$. Arts learning outcomes batik technique shows the average daily practice mastery of 84,3 and the number of students who completed the study reached 92\%. Above data analysis, it is known that the indicators of success has been achieved, so the researchers concluded that (1) the model of projectbased learning can improve learning outcomes Cultural Arts grade students of SMP Negeri 4 Jonggat material batik second semester of academic year 2018/2019; and (2) model project based learning can improve learning outcomes Cultural Art Education students of class VIIA SMP Negeri 4 Jonggat material Batik second semester of the 2018/2019 academic year. 
Keywords : Motivation, learning achievement, Project based learning.

\section{PENDAHULUAN}

Kenyataan di lapangan pada saat ini, meskipun Seni Budaya merupakan pengalaman estetika dasar yang erat hubungannya dengan kehidupan sehari-hari, namun pelajaran yang paling tidak disenangi bagi siswa, karena Seni Budaya bagi sebagian siswa dianggap sebagai pelajaran yang sulit dan rumit, sehingga membutuhkan proses yang sangat panjang, dan belum menjamin untuk memiliki kemampuan yang maksimal dalam mempelajari seni budaya. Dengan Kata lain siswa dalam pengetahuan dasar seni budaya masih kurang. Oleh karena itu, ketidakmampuan sering menimbulkan kejenuhan dan kesulitan belajar terutama didalam menganalisis secara sederhana untuk memecahkan masalah dalam bentuk tugas praktik. Akibatnya prestasi belajar siswa cenderung lebih rendah dengan mata pelajaran lainnya. Sebagai suatu contoh materi pembelajaran Seni Budaya dalam materi seni rupa sub materi batik tulis, sangat sulit dan sangat menghabiskan waktu, tenaga, finansial, dan pikiran.

Salah satu bidang garapan pembelajaran Seni Budaya yang memegang peranan penting ialah pengetahuan konsep yang menunjuk pada pemahaman dasar dan keterampilan menunjuk pada sesuatu yang dilakukan oleh siswa. Suatu jenis keterampilan Seni Budaya adalah proses berkreasi. Keterampilan ini dapat dilihat dari kinerja siswa yang dapat berkembang dan ditingkatkan melalui pengerjaan tugas

Berdasarkan analisis konseptual dan kondisi pendidikan Khususnya Seni Rupa sub materi batik tulis di SMP, ternyata guru dalam keterampilan memilih model dan metode belum dapat mengembangkan iklim pembelajaran yang kondusif bagi peserta didik yang belajar. Hal ini dikarenakan model pembelajaran termasuk juga metode pernbelajaran yang digunakan kurang tepat dan guru terbiasa dengan penggunaan strategi ekspositorik pembelajaran secara klasikal. Pada dasarnya siswa, mempunyai kemampuan dan cara belajar yang berbeda.
Dalam pembelajaran klasikal guru memperlakukan siswa dengan cara yang sama, sehingga perbedaan kemampuan dan cara belajar siswa kurang mendapat perhatian dari guru. Pembelajaran secara klasikal memang perlu dilakukan dengan siswa dan menyadari bahwa tidak semua kebutuhannya dapat dipenuhi, namun harus dicari afternatif cara lain agar siswa dapat belajar sesuai dengan kemampuan dan cara yang dipilihnya.

Dalam proses belajar mengajar guru harus memilih strategi agar siswa dapat belajar secara efektif dan efisien, mengena pada tujuan yang diharapkan. Salah satu strategi itu harus mengetahui teknik-teknik penyajian yang disebut pembelajaran. Pembelajaran hendaknya diupayakan oleh pendidik secara sistematik untuk menciptakan kondisi-kondisi agar peserta didik melakukan kegiatan belajar". Metode adalah cara kerja yang konsisten untuk memudahkan pelaksanaan suatu kegiatan guna mencapai tujuan yang ditentukan.

Banyak metode yang dikenal misalnya, metode ceramah, penugasan, tanya jawab, diskusi, demonstrasi, bermain peran, eksperimen, widya wisata, latihan, simulasi, Project Based Learning . Guru profesional harus dapat memilih model pembelajaran dan metode yang tepat untuk pembelajaran khususnya Seni Budaya dengan ketepatan metode yang diterapkan oleh guru, diharapkan aktivitas guru dan siswa lebih aktif sehingga tujuan yang diharapkan dapat tercapai secara optimal.

Salah satu model dan metode yang cocok untuk pembelajaran Seni Budaya adalah model yang dalam kegiatannya cenderung melakukan banyak tugas praktik, yaitu model Project Based Learning. Model pembelajaran ini di pandang tepat karena memungkinkan siswa dapat selalu belajar dan bekerja atau mengerjakan tugas praktik secara Project Based Learning dalam mencari pengalaman belajarnya.

Model Project Based Learning dalam proses pembelajaran Seni Budaya dapat memberikan pengalaman yang bermakna bagi siswa kelas VIIA SMP Negeri 4 Jonggat 
dalam proses belajar, bila siswa dalam memahami berbagai konsep dan tentang keterampilan atau psikomotorik. Raka Joni dan Unen (1984) menjelaskan "pesan terpenting dari metode Kerja Project Based Learning adalah pemecahan masalah melalui proses Project Based Learning". Perlu ditegaskan bahwa Project Based Learning adalah salah satu model pembelajaran kooperatif. Johnson dan Johnson (1984) menjelaskan "ada empat elemen dasar dalam pembelajaran koperatif yaitu (1) saling ketergantungan positif, (2) interaksi tatap muka (3) akuntabilitas individual, dan (4) keterampilan menjalin hubungan interpersonal". Interaksi koperatif menuntut semua anggota dalam Kerja Project Based Learning dapat saling bertatap muka sehingga mereka dapat melakukan dialog tidak hanya dengan guru tetapi dengan sesama mercka. Interaksi semacam itu diharapkan memungkinkan siswa menjadi sumber belajar bagi semuanya.

\section{KAJIAN PUSTAKA}

\section{A. Motivasi Belajar}

1. Pengertian Motivasi

Banyak sekali, bahkan sudah umum orang menyebut dengan "motif" untuk menunjuk mengapa seseorang itu berbuat sesuatu. Kata "motif", diartikan sebagai daya upaya yang mendorong seseorang untuk melakukan sesuatu. Motif dapat dikatakan sebagai daya penggerak dari dalam dan didalam subjek untuk melakukan aktifitas tertentu demi mencapai suatu tujuan. Berawal dari kata "motif" itu, maka motivasi dapat diartikan sebagai daya penggerak yang telah menjadi aktif. Motif menjadi aktif pada saat saat tertentu, terutama bila kebutuhan untuk mencapai tujuan sangat dirasakan mendesak.

Menurut Mc. Donald (dalam Sardiman ; 2011) motivasi adalah perubahan energi dalam diri seseorang yang ditandai dengan munculnya "feeling" dan didahului dengan tanggapan terhadap adanya tujuan. Dalam kegiatan belajar mengajar, apabila ada seorang siswa, misalnya tidak berbuat sesuatu yang seharusnya dikerjakan, maka perlu diselidiki penyebabnya. Sebabnya bisa berbagai macam, mungkin ia tidak senang, mungkin sakit, lapar, ada problem pribadi dan lain - lain. Hal ini berarti pada diri anak tidak terjadi perubahan energi, tidak terangsang afeksinya untuk melakukan sesuatu, karena tidak memiliki tujuan atau kebutuhan belajar. Keadaan semacam ini perlu dilakukan daya upaya yang dapat menemukan sebab musababnya kemudian mendorong seseorang siswa itu mau melakukan pekerjaan yang seharusnya dilakukan, yakni belajar. Dengan kata lain, siswa perlu diberikan rangsangan agar tumbuh motivasi pada dirinya.

2. Fungsi Motivasi dalam Belajar

Para pelajar biasanya mengurung dirinya dalam kamar untuk belajar, karena akan menghadapi ujian. Kegiatan yang dilakukan itu sebenarnya dilatarbelakangi oleh sesuatu atau secara umum dinamakan motivasi. Motivasi inilah yang mendorong mereka untuk melakukan suatu kegiatan atau pekerjaan.

Dalam belajar sangat diperlukan adanya motivasi. Hasil belajar akan menjadi optimal, kalau ada motivasi. Makin tepat motivasi yang diberikan, akan makin berhasil pula pelajaran itu. Jadi motivasi akan senantiasa menentukan intensitas usaha belajar bagi para siswa.

3. Bentuk - bentuk Motivasi Belajar

Di dalam kegiatan pembelajaran peranan motivasi baik intrinsik maupun ekstrinsik sangat diperlukan. Dengan motivasi, pelajar dapat mengembangkan aktifitas dan inisiatif, dapat mengarahkan dan memelihara ketekunan dalam melakukan kegiatan belajar.

Salah satu bentuk motivasi dalam kegiatan belajar di sekolah adalah minat. Motivasi sangat erat hubungannya dengan minat. Motivasi muncul karena ada kebutuhan, begitu juga minat. Sehingga sangat tepatlah kalau minat merupakan alat motivasi yang pokok.

Proses belajar itu akan berjalan lancar kalau disertai dengan minat. Minat dapat dibangkitkan dengan cara :

a. Membangkitkan adanya suatu kebutuhan

b. Menghubungkan dengan persoalan pengalaman yang lampau

c. Memberi kesempatan untuk mendapatkan hasil yang baik 
d. Menggunakan berbagai macam bentuk belajar (Sardiman, 2011)

Sebagaimana diuraikan di atas, sudah tentu masih banyak cara yang bisa dimanfaatkan untuk menumbuhkan motivasi siswa. Hanya yang terpenting bagi guru adanya motivasi itu dapat dikembangkan dab diarahkan untuk dapat menghasilkan hasil belajar yang bermakna. Sedang indikator yang diambil untuk motivasi belajar peserta didik adalah minat siswa dalam pembelajaran.

\section{B. Hasil Belajar}

Menurut Nana Sudjana hasil belajar adalah suatu akibat dari proses belajar dengan menggunakan alat pengukuran, yaitu berupa tes yang disusun secara terencana, baik tes tertulis, tes lisan, maupun tes perbuatan. Sedangkan S. Nasution, berpendapat bahwa hasil belajar adalah suatu perubahan pada individu yang belajar, tidak hanya mengenai pengetahuan, tetapi juga membentuk kecakapan dan penghayatan dalam diri individu yang belajar.

Hasil belajar adalah hasil yang diperoleh siswa setelah mengikuti suatu materi tertentu dari mata pelajaran yang berupa data kuantitatif maupun kualitatif. Untuk melihat hasil belajar dilakukan suatu penilaian terhadap siswa yang bertujuan untuk mengetahui apakah siswa telah menguasai suatu materi atau belum.

Hasil belajar dapat dilihat dari hasil nilai ulangan harian, nilai ulangan tengah semester, dan nilai ulangan semester. Dalam penelitian tindakan kelas ini, yang dimaksud hasil belajar siswa adalah hasil nilai ulangan harian yang diperoleh siswa dalam mata pelajaran Seni Budaya, khususnya pokok bahasan Pembuatan Batik Tulis.

\section{METODE PENELITIAN}

\section{A. Waktu dan Tempat Penelitian}

Penelitian ini dilaksanakan pada Semester Genap Tahun Pelajaran 2018/2019 bulan Januari s.d Februari 2019 di SMP Negeri 4 Jonggat, yang beralamat di Jln Bypass BILKm 11 Dasan Baru, Desa Sukarara, Kecamatan Jonggat, Kabupaten Lombok Tengah.

\section{B. Subyek dan Obyek Penelitian}

Subyek penelitian ini adalah siswa kelas VIIA SMP Negeri 4 Jonggat Kabupaten
Lombok Tengah semester genap tahun pelajaran 2018/2019 dengan jumlah 25 orang yang terdiri atas 15 siswa laki-laki dan 10 siswa perempuan

Objek dalam penelitian ini adalah keseluruhan proses dan hasil pembelajaran Seni Budaya melalui model pembelajaran Project Based Learning pada Siswa Kelas VIIA SMP Negeri 4 Jonggat Tahun Pelajaran 2018/2019.

\section{Jenis Penelitian}

Jenis penelitian ini, adalah penelitian tindakan kelas (Classroom Action research). Karena menurut Danim (2002) bahwa penelitian tindakan kelas dirancang dan diarahkan untuk memecahkan suatu masalah tertentu. Sedangkan, Arikunto (2009) menjelaskan bahwa penelitian tindakan kelas pada dasarnya untuk meningkatkan mutu belajar siswa serta aktivitas guru dalam mengajar.

\section{Data dan Sumber Data}

Sumber data penelitian ini dikumpulkan dari berbagai sumber yang meliputi ; kata-kata dan tindakan dari guru, teman sejawat, siswa; dan dokumen atau arsip seperti arsip nilai praktik, tugas, foto dan data statistik.

\section{E. Prosedur Penelitian}

Model penelitian tindakan kelas yang digunakan adalah model yang dirancang oleh Kemmis dan Mc Taggart (Wiriatmadja, 2006 : 26-27). Terdapat 4 tahap yang akan dilakukan yaitu perencanaan (planning), tindakan (action), observasi (observation), dan refleksi (reflection).

Hasil refleksi terhadap tindakan yang dilakukan digunakan kembali untuk merevisi rencana jika tindakan yang dilakukan belum berhasil memecahkan masalah.

Berikut model spiral Kemmis dan Robin MC. Taggart : 


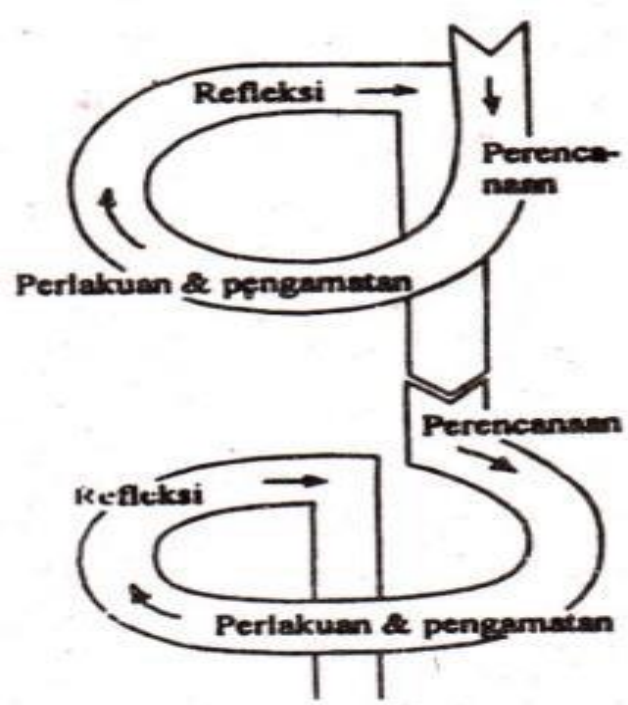

Gambar 3.1 Model Spiral Kemmis dan MC. Taggart

\section{F. Teknik Pengumpulan Data}

Teknik pengumpulan data dalam penelitian ini dilakukan dengan dua cara yaitu teknik penilaian hasil karya dan non tes.

1. Penilaian Hasil Karya

Teknik penilaian hasil karya ini digunakan untuk memperoleh data hasil belajar siswa sesudah diadakan pembelajaran dengan model pembelajaran kelompok dan untuk menjawab permasalahan dalam penelitian. Penilaian hasil karya dilakukan sebanyak dua kali yaitu pada akhir siklus I dan pada akhir siklus II. Hasil dari penilaian hasil karya siklus I dijadikan sebagai acuan dalam perbaikan tindakan siklus II. Penilaian hasil karya diberikan setelah siswa melakukan kegiatan pembelajaran kelompok yang disertai perbaikan pembelajaran oleh guru. Penilaian yang kedua dijadikan sebagai tolak ukur peningkatan keberhasilan siswa dalam pembelajaran Seni Budaya materi batik tulis dengan menggunakan pembelajaran kelompok.

2. Teknik Non Tes

Teknik non tes yang digunakan adalah pengamatan melalui lembar observasi.Observasi dilakukan padasaat berlangsungnya proses pembelajaran. Disamping itu juga observasi dilakukan terhadap peneliti untuk mengetahui sejauh mana peneliti telah melakukan halhal yang diharapkan selama proses pembelajaran berlangsung pada siklus I dan siklus II. Sebelumnya peneliti mempersiapkan lembar observasi untuk dijadikan pedoman dalam pengambilan data. Observasi dilakukan oleh peneliti dibantu oleh guru mata pelajaran..

Adapun aspek-aspek yang terdapat dalam lembar observasi adalah sebagai berikut :

1. Komitmen dalam menghadapi tugas

2. Tekun dalam mengerjakan tugas praktik

3. Ulet dan tidak mudah putus asa dalam menghadapi kesulitan

4. Senang mengerjakan praktik tugas membuat karya

5. Dapat mempertahankan pendapatnya

6. Mampu mengalokasikan waktu untuk mengerjakan tugas

\section{Teknik Analisis Data}

Teknik analisis data dilakukan secara kuantitatif dan kualitatif.

1. Teknik Kuantitatif

Teknik kuantitatif diperoleh dari hasil penilaian tugas yang dilakukan sebanyak dua kali yaitu pada akhir siklus I dan siklus II. Adapun langkah perhitungannya adalah dengan cara menghitung persentase jawaban benar yang diperoleh setiap siswa dengan rumus sebagai berikut :

Nilai persentase $=\frac{\text { skor yang diperoleh siswa }}{\text { skor maksimal }} \times 100 \%$

Dari hasil perhitungan persentase ini, peneliti akan dapat mengetahui sampai sejauh mana penguasaan setiap siswa atas materi yang telah diajarkan. Dengan kata lain, sejauh mana tingkat keberhasilan siswa atas materi yang telah diajarkan ditinjau dari sudut indikator keberhasilan yang telah ditetapkan. Selain itu juga dari hasil perhitungan nilai siswa dari masing-masing tes kemudian dibandingkan antara siklus I dan siklus II. Hasil ini akan memberikan gambaran mengenai persentase peningkatan kemampuan siswa setelah mengikuti pembelajaran.

2. Teknik Kualitatif

Teknik kualitatif ini diperoleh dari data non tes yaitu observasi. Data observasi diambil dari pengamatan terhadap kegiatan siswa dan guru selama pembelajaran berlangsung.

\section{G. Indikator Keberhasilan}


Sebagai indikator keberhasilan yang ingin dicapai dalam penelitian ini adalah meningkatnya motivasi belajar siswa dan hasil belajar siswa dalam proses pembelajaran Seni Budaya Pokok Bahasan Pembuatan Batik Tulis melalui model pembelajaran Project Based Learning pada Siswa Kelas VIIA SMP Negeri 4 Jonggat Tahun Pelajaran 2018/2019. Jika persentase motivasi belajar seluruh siswa mencapai $\geq 75 \%$ atau lebih maka siklus dihentikan dan dinyatakan berhasil, begitu pula pada hasil belajar, jika ketuntasan klasikal sudah mencapai $\geq 85 \%$ maka penelitian ini dikatakan berhasil.

\section{HASIL PENELITIAN DAN PEMBAHASAN}

\section{A. Deskripsi Kondisi Awal}

Motivasi dan hasil belajar Seni Budaya kelas VIIA SMP Negeri 4 Jonggat masih terbilang rendah. Dari hasil kajian terhadap dokumentasi catatan siswa diperoleh data bahwa dari 25 siswa, sebagian besar siswa tidak tepat waktu menyelesaikan tugas, keaktifan siswa di kelas kurang, kemampuan kerja sama secara individu dengan teman kurang serta kemampuan bertanya dan menjawab siswa rendah serta motivasi belajar yang rendah sekitar 56\%.

Selama pembelajaran berlangsung, keaktifan siswa diukur berdasarkan hasil pengamatan aktifitas siswa pada saat implementasi pembelajaran Project Based Learning berlangsung. Hasil observasi tentang pelaksanaan pembelajaran dianalisis secara deskriptif untuk perbaikan dalam pembelajaran berikutnya. Data hasil observasi motivasi belajar siswa dianalisis sebagai berikut :

1. Menghitung banyaknya siswa dalam kelas yang termotivasi atau yang melaksanakan keenam aspek motivasi yang diamati pada saat pembelajaran berlangsung

2. Kemudian jumlah siswa yang termotivasi dipersentasekan dengan rumus :

jumlah siswa yang termotivasi
jumlah semua siswa
Selama pembelajaran berlangsung, kemampuan guru dalam pengelolaan pembelajaran di kelas diukur berdasarkan indikator-indikator yang ditentukan pada lembar pengamatan. Bagaimana kemampuan guru dalam pengelolaan pembelajaran tersebut dan melaksanakan indikator tersebut atau tidak sehingga kemampuan guru dinilai baik apabila indikator yang telah ditentukan dalam lembar observasi dapat dilaksanakan oleh guru dengan baik.

Pada saat guru menyampaikan materi, siswa cenderung ramai dan berbicara dengan teman sebangkunya. Hal tersebut terjadi karena guru belum melaksanakan pembelajaran yang aktif, inovatif, kreatif dan menyenangkan bagi siswa.

Disamping itu guru juga belum memanfaatkan media pembela-jaran yang ada secara baik dan memadai. Sehingga siswa merasa tidak atau kurang berminat mengikuti pembelajaran Seni Budaya materi batik tulis, terasa membosankan.

Berdasarkan kajian tugas praktik ke1 dari 25 siswa, tercatat hanya 14 siswa atau $56 \%$ siswa yang tuntas belajar dengan nilai rata-rata penguasaan praktik sebesar 63,6. Untuk lebih jelasnya dapat dilihat pada tabel dibawah ini.

Tabel 4.1 : Hasil Pembelajaran Seni Budaya Pra Siklus

\begin{tabular}{|c|c|c|c|}
\hline No. & Aspek & $\begin{array}{c}\text { Rata- } \\
\text { rata }\end{array}$ & Keterangan \\
\hline 1 & Motivasi & $56 \%$ & \multirow{3}{*}{$\begin{array}{l}\text { Indikator } \\
\text { kinerja rata- } \\
\text { rata } \geq 75 \\
\text { dengan } \\
\text { ketuntasan } \\
\geq 85 \% \\
\text { belum } \\
\text { tercapai. }\end{array}$} \\
\hline 2 & $\begin{array}{l}\text { Nilai } \\
\text { praktik/hasil } \\
\text { karya }\end{array}$ & 63,6 & \\
\hline 3 & $\begin{array}{l}\text { Ketuntasan } \\
\text { klasikal }\end{array}$ & $60 \%$ & \\
\hline
\end{tabular}

\section{B. Deskripsi Hasil Siklus I}

\section{Perencanaan (Planning)}

Pada tahap perencanaan siklus I, peneliti telah menyusun instrumen berupa RPP 1 tentang teknik mencuci bahan kain batik, dan penerapan praktik mencuci kain bahan yang akan dijadikan kain batik tulis, mempersiapkan LKS 1 yang akan digunakan untuk pembelajaran pertemuan pertama. Disamping itu peneliti juga menyusun lembar observasi yang akan digunakan dalam proses pembelajaran. 


\section{Pelaksanaan (Action)}

a. Pertemuan pertama

Tindakan kelas siklus I mulai dilaksanakan pada hari, Senin, 7 Januari 2019. Peneliti dibantu oleh 1 orang kolaburator atau observer untuk melaksanakan pengamatan sekaligus bertugas mendokumentasi proses pembelajaran.

Langkah awal yang dilakukan peneliti pada tindakan siklus 1 ini adalah melakukan apersepsi dengan memberikan beberapa pertanyaan tentang pengetahuan yang sudah dimiliki siswa dan segala sesuatu yang berkaitan dengan kelasnya. Dari beberapa pertanyaan yang diberikan itu anak mulai tertarik dan antusias tentang materi yang akan disampaikan. Dari apersepsi itu, kemudian peneliti mengkomunikasikan tujuan pembelajaran yang ingin dicapai dan menyampaikan materi yang akan diajarkan yaitu mendeskripsikan teknik mencuci kain bahan batik tulis. Langkah berikutnya peneliti memberikan penjelasan tentang model pembelajaran Project Based Learning yang akan digunakan dalam pembelajaran. Semua siswa tertuju dan memperhatikan penjelasan peneliti. Pada saat memberikan penjelasan, siswa diminta untuk menanyakan hal-hal yang belum dipahami. Dalam mengerjakan tugas praktik peneliti membentuk kelompok tugas praktik tersebut yang terdiri dari atas 5 sampai 6 siswa. Karena dari ke 25 siswa maka dalam menentukan kelompok belajar berdasarkan urutan tunjukan dari guru, karena akan terasa adil, dalam kelompok sebaran anak laki-laki dan perempuan akan mendekati imbang, sehingga penyebaran kemampuan anak tiap kelompok dapat merata. Setelah semua siswa mengetahui kelompoknya mereka berkumpul sesuai dengan kelompok-kelompok yang telah dibentuk. Kemudian peneliti membagikan Lembar Kerja Siswa 1 kepada setiap kelompok 1 tugas. Selama siswa belajar di dalam kelompok, peneliti berkeliling untuk mengawasi kinerja kelompok dan membantu secara proporsional kepada kelompok yang mengalami kesulitan dalam memecahkan atau menyelesaikan tugas tersebut.

Setelah selesai kegiatan belajar dan mengajar peneliti menyempatkan diri untuk berdiskusi dengan kolaborator tentang jalannya proses pembelajaran dan jalannya kerja kelompok maupun diskusi kelas yang berlangsung saat itu, dan minta masukan atau saran untuk perbaikan agar pertemuan berikutnya dapat terlaksana dengan lebih baik lagi.

\section{b. Pertemuan ke dua}

Pertemuan ke dua dilaksanakan pada hari Senin, 14 Januari 2019. Kegiatan yang dilakukan adalah mencanting bahan kain yang akan dijadikan batik tulis. Secara kelompok, memperhatikan tayangan video tentang teknik mencating yang benar, selesai melihat tayangan tersebut, lalu perwakilan dari masing-masing kelompok mempraktikkan dengan selembar kain kecil, secara bergantian, sesuai arahan gurunya. Setelah lancar menggunakan alat canting, dan bisa menuliskan malamnya di lembar kain kecil, lalu semua kelompok diberi waktu 45 menit menyelesaikan tugas mencanting tersebut sesuai kelompoknya dengan arahan dan petunjuk dari guru menggunakan bahan kain selebar $2 \times 1$ meter.

\section{c. Pertemuan ke tiga}

Pertemuan ke tiga dilakukan pada hari Senin, 21 Januari 2019. Guru mengkondisikan kelas, melalui kegiatan berdo'a, mengucapkan salam, mengabsen siswa, dan menjelaskan tujuan pembelajaran yang akan dicapai. Siswa secara kelompok, mengerjakan Lembar Kerja Siswa mengenai konsep mewarnai motif dan tekniknya. Waktu yang disediakan 15 sampai 20 menit, kemudian masing-masing kelompok, melalui perwakilan kelompok, membacakan hasil diskusi. Guru menegaskan kembali mengenai materi hasil diskusi, setelah itu siswa secara kelompok mengerjakan tugas praktik dengan materi mewarnai motif pada kain yang telah dicanting. Semua anak pada masing-masing kelompok mengerjakan tugas mewarnai motif, sesuai dengan kesepakan masingmasing kelompok. Kegiatan selesai, siswa bersama guru menyimpulkan materi yang telah diajarkan.

\section{Observasi (Observation)}

Bersama kolaborator, peneliti mengamati proses pembelajaran yang sedang berlangsung, yang meliputi pengamatan 
aktivitas siswa dan aktivitas guru dalam menyampaikan pembelajaran, menggunakan lembar observasi yang telah disiapkan. Disamping itu pengamat juga mencatat segala peristiwa yang sedang terjadi selama proses pembelajaran berlangsung.

Pada pengamatan aktivitas siswa ada beberapa aspek yang diamati terutama mengenai motivasi siswa dalam mengikuti proses pembelajaran. Ada enam aspek utama yang diamati pada motivasi siswa dalam mengikuti proses pembelajaran. Keenam aspek itu meliputi : komitmen dalam menghadapi tugas, tekun dalam belajar, ulet dan tidak mudah putus asa dalam menghadapi kesulitan, senang mencari dan memecahkan masalah-masalah dalam tugas kerja kelompok, dapat mempertahankan pendapatnya, dan mampu mengalokasikan waktu untuk mengerjakan tugas praktik.

Setelah melakukan observasi motivasi pada siklus I diperoleh data bahwa pembelajaran kelompok pada kelas VIIA SMP Negeri 4 Jonggat menunjukkan hasil yaitu sebesar $68 \%$. Dari hasil tugas siklus I, hasil belajar penguasaan praktik tercatat 18 siswa atau $72 \%$ siswa yang tuntas belajar dengan nilai rata-rata penguasaan praktik (psikomotorik) sebesar 72,6. Untuk lebih jelasnya dapat dilihat pada tabel dibawah ini.

Tabel 4.2 : Hasil Pembelajaran Seni Budaya Siklus I

\begin{tabular}{|c|c|c|c|}
\hline No. & Aspek & $\begin{array}{c}\text { Rata- } \\
\text { rata }\end{array}$ & Kete \\
\hline 1 & tenter & 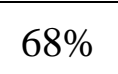 & \multirow{3}{*}{$\begin{array}{l}\text { Indikator } \\
\text { kinerja rata- } \\
\text { rata } \geq 75 \\
\text { dengan } \\
\text { ketuntasan } \geq \\
85 \% \text { belum } \\
\text { tercapai. }\end{array}$} \\
\hline 2 & $\begin{array}{l}\text { praktik/hasil } \\
\text { karya }\end{array}$ & 72,6 & \\
\hline 3 & klasikal & $72 \%$ & \\
\hline
\end{tabular}

\section{Refleksi (Reflektion)}

Berdasarkan hasil obervasi siklus I, ternyata proses dan hasil belajar belum mencapai hasil yang diharapkan. Hal ini disebabkan oleh berbagai permasalahan yang muncul dalam pembelajaran Project Based Learning, baik dari siswa maupun dari pihak guru. Permasalahan dari siswa diantaranya adalah beberapa siswa dalam kelompok belum memahami betul konsep mengenai teknik mencuci kain, mendesain, mewarnai motif, serta mewarnai dasar, sehingga masing-masing ketua kelompok mengalami kesulitan , dengan kata lain belum sesuai dengan kemampuannya. Hal ini menyebabkan kurangnya penguasaan materi yang menjadi tanggung jawabnya, sehingga dalam kerja kelompok ada siswa dalam kelompok yang tidak tahu akan tugasnya, siswa pasif dan kurang aktif pada kelompoknya serta idenya sangat terbatas, sehingga pada saat kerja praktik mereka kurang mampu mengerjakan tugas praktik yang menjadi tanggung jawabnya. Hal ini menyebabkan teman yang lain tidak bisa menerima kehadirannya, karena kurang bisa menangkap dan hasil kesepakan kelompok sebelumnya. Permasalahan dari guru diantaranya adalah terlalu cepatnya penjelasan guru sehingga terdapat sebagian siswa dalam kelompok yang belum memahami konsep dan teknik mengenai materi dari pertemuan pertama, sampai pertemuan keempat, guru kurang memotivasi siswa dalam belajar di kelompok dan kurang memperhatikan penggunaan waktu dengan baik.

Berdasarkan hasil refleksi, ketercapaian nilai rata-rata kelas memperoleh nilai 72,6 dan ketuntasan kelas mencapai 72 $\%$, maka dilakukan tindakan kelas siklus II dengan melakukan perbaikan-perbaikan strategi, teknik dan metode yang lebih efektif untuk mencapai standar tersebut. Dengan cara menjelaskan kembali tentang materi Konsep dan Teknik Mencuci kain, Mendesain, Mewarnai motif dan Mewarnai dasar, serta menegaskan kembali agar dalam pembentukan kelompok betul-betul sesuai dengan kemampuannya, sehingga pada saat praktik kerja kelompok, dalam kelompok betul-betul menguasai dan tidak merasa minder, sehingga praktik kerja kelompok dapat hidup dan berjalan dengan lancar.

\section{Deskripsi Hasil Siklus II \\ 1. Perencanaan (Planning)}

Perencanaan pada siklus II, peneliti menyusun RPP 2 tentang membatik teknik tulis mengenai konsep dan teknik serta penerapan penguncian warna, penglorotan malam, pembersihan malam dan pengemasan hasil batik tulis dengan menyiapkan Lembar 
Kerja Siswa . Guru membagi kelompok belajar seperti pada siklus I.

\section{Pelaksanaan (Action)}

\section{a. Pertemuan pertama}

Tindakan kelas pada siklus II pertemuan pertama dilaksanakan pada hari Senin, 28 Januari 2019, dengan materi yang berbeda yaitu menerapkan teknik mengunci warna, menglorot malam, membersihkan malam, dan mengemas hasil batik tulis. Disini peneliti masih menggunakan kolaburator yang sama. Dalam mengawali pelaksanaan tindakan kelas pada siklus II, guru memberikan apersepsi lagi seperti pada siklus I. Guru menjelaskan materi yang akan dipelajari yaitu mendeskripsikan konsep dan teknik tentang konsep 4P (penguncian warna, penglorotan malam, pembilasan dan pengemasan kain batik tulis) Setelah selesai memberi penjelasan guru memberikan Lembar Kerja Siswa 3. Guru membagi kerja kelompok seperti pada kelompok pada siklus I.. Setelah masing-masing kelompok selesai membahas tugas LK, selanjutnya guru menyuruh masing-masing kelompok untuk keluar mempersiapkan media yang ada, dan mengerjakan tugas praktik materi penguncian warna. Karena pekerjaan ini sangat beresiko tinggi, maka pengerjaannya melalui perwakilan kelompok saja, akan tetapi tidak mengurangi kegiatan kerja kelompok. Selama kegiatan penguncian warna berlangsung, semua kelompok memperhatikan perwakilan tiap kelompok mempraktikkan teknik mengunci warna. Waktu penguncian melalui perendaman kain berlangsung 6 sampai 12 jam. Pada waktu kegiatan praktik penguncian warna, semua kelompok diberi waktu oleh guru pembimbingnya, untuk menanyakan masalah yang berhubungan dengan materi yang dibahas. Kemudian peneliti mengkonfirmasi jawaban yang diberikan dan menegaskan jawaban yang benar. Siswa bersama guru menyimpulkan materi yang telah dibahas.

\section{b. Pertemuan ke dua}

Pertemuan kedua proses pembelajaran dilaksanakan pada hari Senin, 4 Februari 2019. Sebelum memulai praktik, guru memberikan waktu untuk bertanya mengenai teknik nglorot malam kepada semua kelompok. Guru menegaskan kembali teknik nglorot malam yang benar kepada semua kelompok. Kegiatan dimulai, semua perwakilan kelompok mempraktikan teknik nglorot yang benar sesuai dengan bahan kain dari tiap kelompok.

\section{c. Pertemuan ke tiga}

Tindakan kelas siklus II pertemuan ketiga dilaksanakan pada hari Senin, 11 Februari 2019. Pada tahap pendahuluan, peneliti menanyakan keadaan siswa, mengondisikan kelas sehingga semua siswa berada dikelompoknya untuk mendiskusikan teknik pembilasan bahan kain yang akan dilorot, terutama tentang hal yang belum dipahami.

Masing-masing

kelompok memaparkan teknik pembilasan yang benar kepada kelompok lain, kemudian guru menegaskan kembali hasil diskusi yang dibahas. Semua kelompok menuju ke depan kelas, dengan disaksikan oleh masing-masing kelompok mempraktikan cara pembilasan sesuai dari arahan guru pembimbingnya, dan setelah itu semua bahan kain tersebut, dijemur dengan tidak terkena sinar matahari langsung. Peneliti juga membimbing siswa dan mendorongnya untuk berpikir sendiri, menganalisis sendiri dengan memanfaatkan pengalamannya sehingga mereka dapat mengem-bangkan pemikirannya yang dapat dipakai untuk menyelesaikan tugas-tugas praktik yang telah dan akan dikerjakan.

\section{Observasi (Observation)}

Setelah dilakukan tindakan pada siklus II dengan beberapa perbaikan dan dilakukan observasi terhadap proses pembelajaran, diperoleh data bahwa aktivitas siswa dalam pembelajaran Project Based Learning sudah menunjukkan hasil yang memuaskan yaitu sebesar $88 \%$. Sementara itu dari hasil tugas siklus II, prestasi belajar penguasaan psikomotorik tentang Penguncian warna, Penglorotan malam, Pembilasan, dan Pengemasan, tercatat 23 siswa atau 92\% siswa yang tuntas belajar dengan nilai ratarata praktik atau penguasaan psikomotorik sebesar 84,3. Untuk lebih jelasnya dapat dilihat pada tabel dibawah ini.

\section{Tabel 4.3 : Hasil Pembelajaran Seni Budaya Siklus II}




\begin{tabular}{|c|c|c|c|}
\hline No. & Aspek & $\begin{array}{c}\text { Rata- } \\
\text { rata }\end{array}$ & Keterangan \\
\hline 1 & Motivasi & $88 \%$ & \multirow{3}{*}{$\begin{array}{l}\text { Indikator } \\
\text { kinerja rata- } \\
\text { rata } \geq 75 \\
\text { dengan } \\
\text { ketuntasan } \\
\text { klasikal } \geq \\
85 \% \text { sudah } \\
\text { tercapai. }\end{array}$} \\
\hline 2 & $\begin{array}{l}\text { Nilai } \\
\text { praktik/hasil } \\
\text { karya }\end{array}$ & 84,3 & \\
\hline 3 & $\begin{array}{l}\text { Ketuntasan } \\
\text { klasikal }\end{array}$ & $92 \%$ & \\
\hline
\end{tabular}

Pada siklus II ini, dengan motivasi, penjelasan dan bimbingan guru secara menyeluruh pembelajaran sudah meningkat. Dalam siklus ini telah memenuhi indikator yang diharapkan. Oleh karena itu pelaksanaan tindakan kelas sudah dirasa cukup, dan tidak akan dilakukan tindakan siklus berikutnya.

\section{Refleksi (Reflektion)}

Setelah dilakukan tindakan pada siklus II dengan beberapa perbaikan. Pengamatan yang dilakukan terhadap pembelajaran juga berjalan dengan baik, sehingga diperoleh data bahwa hasil belajar siswa mengalami peningkatan jika dibandingkan pada siklus I. Pada siklus II rata-rata nilai kelas mencapai 84,3 dan ketuntasan belajar mencapai $92 \%$. Ini berarti tindakan kelas pada siklus II telah mencapai indikator yang diharapkan.

Pada siklus II ini, dengan memberi motivasi kepada siswa, serta penjelasan dan bimbingan yang terarah oleh peneliti, secara menyeluruh siswa sudah mempunyai keberanian untuk berekspresi menuangkan ide dan gagasannya untuk menghasilkan karya yang terbaik. Walaupun masih dijumpai sedikit kekurangan pada saat siswa melakukan praktik mengerjakan tugas, namun hal ini masih dianggap sesuatu yang wajar. Hal ini tidak menjadi masalah bagi peneliti dalam membuat evaluasi untuk mengetahui tingkat keberhasilan hasil belajar siswa. Sehingga secara keseluruhan hasil belajar siswa mengalami peningkatan pada siklus II ini. Pada tabel 4.3 untuk hasil belajar siswa setelah diadakan tindakan pada siklus II mengalami peningkatan yang sangat baik. Terbukti pencapaian hasil belajar siswa yang sudah memenuhi harapan peneliti. Sehingga dapat disimpulkan bahwa pada siklus ini telah memenuhi indikator yang diinginkan oleh peneliti. Oleh karena itu pelaksanaan tindakan kelas sudah dirasa cukup, dan tidak akan dilakukan tindakan berikutnya. Hasil penelitian menunjukkan, motivasi dan hasil belajar siswa kelas VIIA mengalami peningkatan menggunakan model pembelajaran Project Based Learning.

\section{Pembahasan}

\section{Pembahasan Siklus I}

Pada siklus I, pembelajaran telah berlangsung dengan baik, sebagian besar siswa sudah cukup aktif mengikuti kegiatan pembelajaran yang dilakukan oleh peneliti. Siswa belajar melalui diskusi kelompok, dan praktik kerja kelompok, pembahasan LKS. Pada pertemuan pertama, kegiatan pembelajaran belum berjalan sebagaimana yang diharapkan. Hal ini dikarenakan sebagian mengenai tugas siswa disibukkan dengan kerja sendiri-sendiri untuk mengerjakan lembar kerja dan langsung mengerjakan secara kelompok sehingga menyita waktu untuk menyelesaikan kegiatan yang lain. Pada pertemuan kedua, pelaksanaan pembelajaran dengan model pembelajaran Project based Learning telah berjalan dengan baik. Para siswa sudah memahami dan terbiasa dengan model pembelajaran tersebut. Disamping siswa sudah bisa membagi waktu dengan baik dalam menyelesaikan tahapantahapan pembelajaran dengan baik seperti mengerjakan Lembar Kerja, diskusi kelompok dan praktik kerja kelompok. Hasil analisis lembar observasi motivasi belajar seni Budaya diketahui adanya peningkatan motivasi belajar siswa dengan telah melaksanakan keenam aspek motivasi yang diamati yaitu sebanyak 17 siswa atau $68 \%$. Selain itu, dari hasil nilai praktik siklus I hasil belajar penguasaan psikomotorik materi mencuci bahan kain, mendesain, mencanting, mewarnai motif, dan mewarnai dasar, tercatat 18 siswa atau $72 \%$ siswa yang tuntas belajar dengan nilai rata-rata penguasaan psikomotorik sebesar 72,6. Untuk lebih jelasnya dapat dilihat pada grafik dibawah ini. 


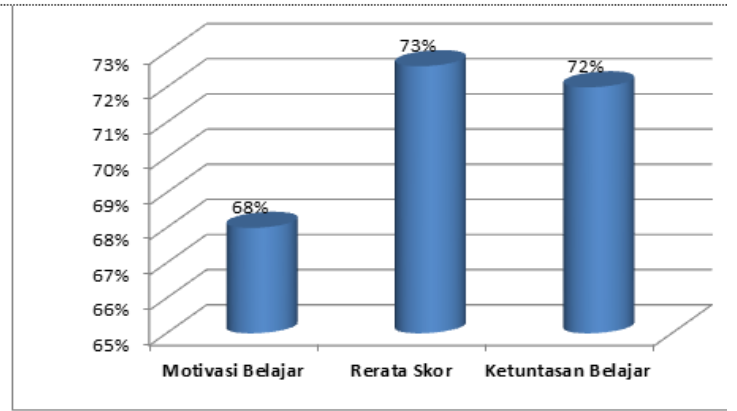

Gambar 4.1 : Grafik Peningkatan Skor Ratarata Motivasi, Hasil Belajar dan Ketuntasan

Belajar Siswa pada Siklus I

\section{Pembahasan Siklus II}

Pada siklus II, pelaksanaan pembelajaran berlangsung dengan baik. Peneliti dan siswa telah melaksanakan pembelajaran sesuai yang diharapkan, sehingga kegiatan pembelajaran dapat terlaksana dengan baik. Pada pertemuan pertama maupun pertemuan kedua, siswa sudah aktif dan terbiasa dengan kegiatan seperti diskusi kelompok, tugas LKS, presentasi kelas, dan pembahasan soal. Semua tahapan-tahapan dalam model pembelajaran ini dapat terlaksana dengan baik dan lancar, sehingga alokasi waktu yang tersedia dapat telaksana sesuai dengan yang telah direncanakan.

Berdasarkan analisis data hasil observasi, motivasi belajar siswa dan hasil belajar Seni Budaya siswa kelas VIIA mengalami peningkatan. Dari hasil analisis lembar observasi motivasi belajar, menunjukkan banyaknya siswa yang termotivasi pada saat kegiatan pembelajaran. Berdasarkan hasil observasi motivasi belajar, siswa yang berkategori tinggi pada setiap aspek motivasi telah mencapai lebih dari $75 \%$ yaitu sebanyak 22 siswa atau 88\%. Selain itu, dari hasil tugas praktik siklus II prestasi belajar penguasaan psikomotorik tentang materi mengunci warna, nglorot malam, pembersihan bahan batik, dan pengemasan hasil karya ada 23 siswa atau $92 \%$ siswa yang tuntas belajar dengan nilai rata-rata penguasaan psikomotorik sebesar 84,3 . Untuk lebih jelasnya dapat dilihat pada gambar dibawah ini.

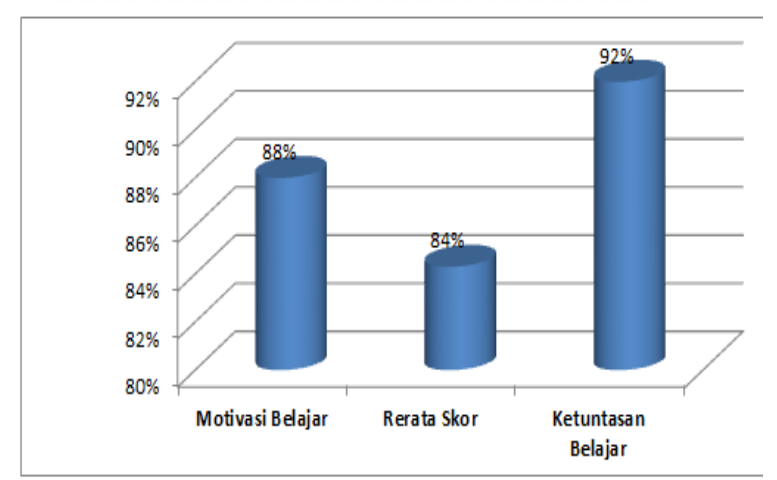

Gambar 4.2. : Grafik Peningkatan Rerata Motivasi, Hasil Belajar dan Ketuntasan Belajar Siswa pada Siklus II

\section{Pembahasan Antarsiklus}

Dalam setiap proses pembelajaran berlangsung dengan baik pada siklus I maupun siklus II, sebagian besar siswa aktif mengikuti kegiatan. Melalui Kerja kelompok, siswa dilatih untuk bekerja secara mandiri dan bertanggung jawab, bekerjasama, menentukan keputusan dan menghargai pendapat orang lain. Dengan kerja kelompok, siswa diharapkan mampu bertanggung jawab terhadap tugas yang diembannya dan melalui tugas praktik secara kelompok dapat melatih siswa untuk mengembangkan kreasi, baik kreasi sendiri, maupun kreasi teman kelompok, dan kreasi teman antar kelompok, sehingga harapannya mampu bersosialisasi dengan siswa kelompok sendiri, ataupun sosialisasi dengan kelompok lain.

Berdasarkan hasil observasi, motivasi belajar siswa pada siklus II mengalami peningkatan yang cukup signifikan dibandingkan dengan kegiatan pembelajaran pada kondisi awal maupun pada siklus I. Peningkatan motivasi belajar siswa itu dapat dilihat pada setiap aspek motivasi belajar yang diamati telah mencapai lebih dari $75 \%$, yang artinya banyaknya siswa yang mencapai kategori tinggi pada keenam aspek motivasi telah memenuhi indikator keberhasilan $(\geq 75 \%)$.

Selain itu, hasil belajar Seni Budaya siswa kelas VIIA mengalami peningkatan baik rata-rata nilai praktik atau penguasaan psikomotorik maupun ketuntasan belajar secara klasikal dibandingkan tugas praktik hasil belajar Seni Budaya pada kondisi awal maupun siklus I. 
Untuk lebih jelasnya dapat dilihat pada gambar dibawah ini.

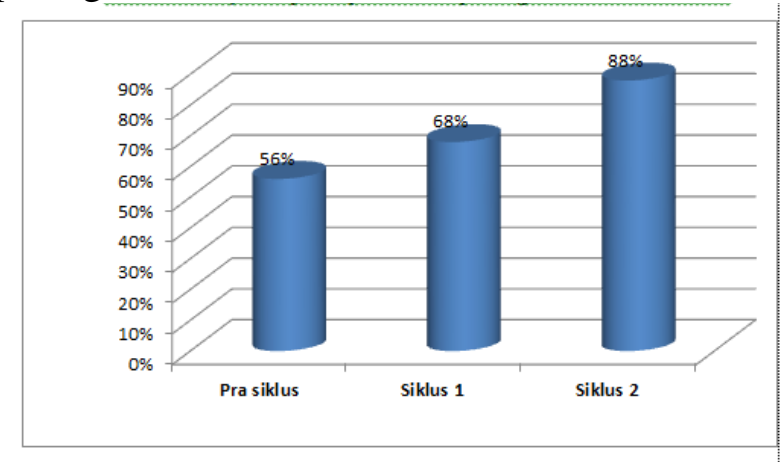

Gambar 4.3 : Grafik Perbandingan

Peningkatan Rerata Motivasi Siswa antar Siklus

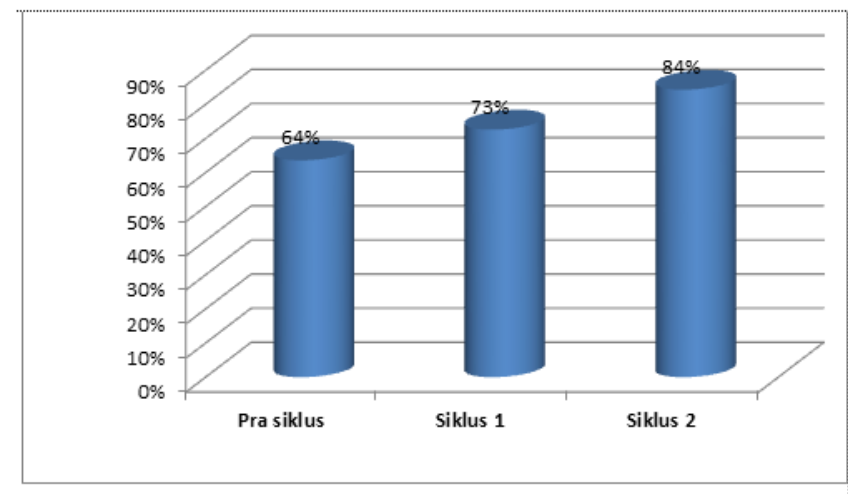

Gambar 4.4 : Grafik Perbandingan Peningkatan Rerata Nilai Praktik Siswa antar Siklus

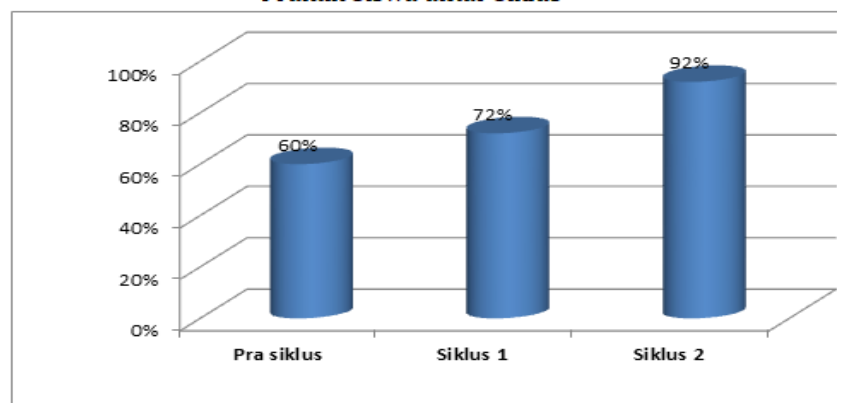

Gambar 4.5 : Grafik Perbandingan Peningkatan Rerata Ketuntasan Klasikal antar Siklus

Dari grafik diatas, jelas menunjukkan adanya peningkatan baik motivasi belajar, nilai rata-rata kelas maupun ketuntasan belajar siswa secara klasikal dari kondisi awal hingga kondisi akhir. Peningkatan motivasi belajar siswa kelas VIIA dari kondisi awal $56 \%$ menjadi $68 \%$ pada siklus I dan $88 \%$ pada siklus II atau kondisi akhir. Sementara itu nilai rata-rata nilai praktik atau penguasaan psikomotorik siswa kelas VIIA dari kondisi awal 63,6 menjadi 72,6 pada siklus I dan dan 84,3 siklus II atau kondisi akhir. Sedangakan peningkatan ketuntasan belajar siswa kelas VIIA dari kondisi awal $60 \%$ menjadi $72 \%$ pada siklus I dan $92 \%$ siklus II atau kondisi akhir. Dengan demikian motivasi belajar, ketuntasan belajar maupun hasil belajar atau nilai rata-rata penguasaan psikomotorik Seni Budaya materi Batik Tulis SMP Negeri 4 Jonggat telah mencapai indikator keberhasilan yaitu nilai rata-rata $\geq 75$ dan ketuntasan belajar lebih dari $\geq 85 \%$.

\section{KESIMPULAN}

Berdasarkan hasil penelitian ini dapat disimpulkan bahwa model pembelajaran project based learning dapat meningkatkan motivasi dan hasil belajar Seni Budaya siswa kelas VIIA SMP Negeri 4 Jonggat pada pokok bahasan Batik Tulis pada semester genap tahun pelajaran 2018/2019.

Berdasarkan hasil penelitian ini, maka para guru disarankan untuk menggunakan model pembelajaran project based learning sebagai salah satu alternatif untuk meningkatkan motivasi dan hasil belajar siswa pada pembelajaran Seni Budaya dan mata pelajaran lainnya. Para guru juga diharapkan dapat memperkaya penerapan beberapa model pembelajaran yang lain untuk meningkatkan motivasi dan hasil belajar siswa pada pembelajaran Seni Budaya. Disamping itu, model pembelajaran project based learning juga dapat diterapkan pada mata pelajaran lain.

\section{DAFTAR PUSTAKA}

Arikunto,S., 2006. Prosedur Penelitian Suatu Pendekatan Praktik. Jakarta : ineka Cipta.

Arikunto, Suharsimi, Suhardjono, dan Supardi, 2009. Penelitian Tindakan Kelas. Jakarta: Bumi Aksara

Danim, S.2002. Menjadi peneliti Kualitatif. Bandung : CV. Pustaka Setia.

Harminarto, S. dan Hamzah, U. 2003. Teori Motivasi dan Aplikasinya dalam Penelitian. Gorontalo : Nurul Jannah.

Johnson, David W. And Roger T. Johnson. 1984. Cooperation in the Classroom, Edina

Minnesota. A publication Book Company. 
Mulyasa. 2009. Penelitian Tindakan Kelas. Bandung: PT Remaja Rosdakarya

Moleong, Lexy J. 2002. Metodologi Penelitian Kualitatif. PT Remaja Bandung: Rosdakarya.

Kemendikbud. 2013. Kemendikbud No. 54, 64, 65, 66 tentang : Standar Kelulusan,

Standar Isi, Standar Proses, Setandar Penilaian.

Raka Joni dan Linen (1984). Belajar dan Pembelajaran. Jakarta: Depdikbud Supriyanto.E.,2007. Inovasi Pendidikan. Solo : UMS Press.

Sardiman, Arief Sukadi. 2006. Media Pendidikan: Pengertian, Pengembangan, dan Pemanfaatannya. Jakarta: Raja Grafindo Persada. 